\title{
Status of Micro and Macro Nutrients in Patients with Type 2 Diabetes Mellitus Suggesting the Importance of Cation Ratios
}

\author{
Ramesh Ramaswamy ${ }^{1}$, Niranjan Gopal', Sony Joseph ${ }^{1}$, Sathish Babu Murugaiyan', \\ M. Joseph ${ }^{2}$, Densely Jose'2, V. Kuzhandaivelu', A. Velayutharaj ${ }^{3}$ \\ ${ }^{1}$ Department of Biochemistry, Mahatma Gandhi Medical College and Research Institute, SBV, Pillaiyarkuppam, \\ India \\ ${ }^{2}$ Department of Chemistry, Regional Research Center in Chemistry (M. G. University), M. A College, \\ Kothamangalam, India \\ ${ }^{3}$ Department of Biochemistry, Chennai Medical College, Hospital \& Research Centre, Trichy, India \\ Email: "rameshrdr30@gmail.com
}

Received 15 July 2016; accepted 7 August 2016; published 10 August 2016

Copyright (C) 2016 by authors and Scientific Research Publishing Inc.

This work is licensed under the Creative Commons Attribution International License (CC BY).

http://creativecommons.org/licenses/by/4.0/

(c) (i) Open Access

\begin{abstract}
Background: Type 2 Diabetes Mellitus (T2DM) is a chronic polymetabolic disorder characterized by chronic hyperglycemia resulting from resistance to insulin action or inadequacy of insulin secretion. Role of the micro \& macro nutrients in the pathogenesis of T2DM has not been studied thoroughly. The aim of this study was to evaluate the status of calcium, magnesium, zinc and chromium in relation to HbA1c in a group of subjects with T2DM patients. Methodology: The study comprised of seventy three patients with T2DM, attending the OP of a tertiary care medical college hospital. Thirty four individuals were with HbA1c $<7 \%$ (group 1) and thirty nine with HbA1c $\geq 7 \%$ (group 2). Cation concentrations were determined using Atomic Absorption Spectroscopy and HbA1c by ion exchange chromatography. Results: The individual cation concentrations were not significantly different between the groups. Association of these serum ion concentrations with the glycemic control in group 2 (HbA1c 7\%) was noted. Significant association of cation ratios with glycemic control was noted. Conclusion: The concentration of magnesium, zinc and chromium were low in subjects with poor glycemic control (HbA1c $>7 \%)$. Cation ratios were significantly associated with the glycemic control in T2DM.
\end{abstract}

\section{Keywords}

T2DM, HbA1c, Trace Elements, Cation Ratio

\footnotetext{
${ }^{*}$ Corresponding author.
}

How to cite this paper: Ramaswamy, R., Gopal, N., Joseph, S., Murugaiyan, S.B., Joseph, M., Jose, D., Kuzhandaivelu, V. and Velayutharaj, A. (2016) Status of Micro and Macro Nutrients in Patients with Type 2 Diabetes Mellitus Suggesting the Importance of Cation Ratios. Journal of Diabetes Mellitus, 6, 191-196. http://dx.doi.org/10.4236/jdm.2016.63021 


\section{Introduction}

Type 2 diabetes mellitus (T2DM) constitutes 90\% of diabetic population and also shows increasing prevalence worldwide [1]. Trace elements play important role in glucose metabolism by serving as cofactors or components for enzyme involved in glucose metabolism enhancing insulin action by activation of insulin receptor. Being an integral part of antioxidant system they are also implicated in various complication of T2DM. A delicate balance among micronutrients exists due to the synergistic and antagonistic effects existing among them and studies have shown that the status of many trace metals in T2DM patient differs significantly from healthy individuals suggesting some imbalance in micronutrient status among people with T2DM. Trace elements enhance insulin action by activation of insulin receptor, and serve as a cofactors or compounds for enzymes involved in glucose metabolisms increasing insulin sensitivity and also important component of antioxidants system [2]. Elevated cytosolic free calcium concentration is the primary trigger for insulin release and magnesium is a cofactor in the glucose transporting mechanism of cell membrane. Zinc and chromium are important on insulin action and Zinc also part of antioxidant system. The present study was aimed to evaluate the status of $\mathrm{Ca}, \mathrm{Mg}, \mathrm{Zn}$ and $\mathrm{Cr}$ in relation to $\mathrm{HbA}_{1} \mathrm{C}$ in T2DM patients.

\section{Materials and Methods}

This case-control study was conducted after obtaining the clearance from the Institutional Human Ethical committee. Seventy three patients with newly diagnosed T2DM were included in this study and they were divided into two groups based on their $\mathrm{HbA}_{1 \mathrm{c}}$ values. Group 1 with $\mathrm{HbA}_{1 \mathrm{c}} \leq 7 \%(\mathrm{n}=34)$ and Group 2 with $\mathrm{HbA}_{1 \mathrm{c}} \geq 7 \%$ ( $\mathrm{n}=39$ ) diabetic cases.

Analytical grade acids (Merck), standard certified solutions in nitric acid containing $1000 \mathrm{mg} / \mathrm{L}$ (PerkinElmer), TritonX-100 (Fisher Scientific), $\mathrm{LaCl}_{3}$ (Sigma-Aldrich) were used. Water quality was secured by treatment on a Millipore Synergy U.V water treatment system. Working standards of zinc was prepared with $5 \%(\mathrm{v} / \mathrm{v})$ glycerol and that of chromium using a $0.2 \%$ solution of nitric acid containing $0.2 \%$ TritonX-100. Metals were estimated as per standard methods [5] [6] using Atomic Absorption AAS (Perkin Elmer AAnalyst 700, with electrographite furnace; 4.11 - 11 fitted with autosampler and deuterium lamp background correction; slit width $0.7 \mathrm{~nm}$, oxidant flow rate; $16.0 \mathrm{~L} / \mathrm{min}$ and acetylene flow rate $7.8 \mathrm{~L} / \mathrm{min}$. Flame AAS was used for Ca and $\mathrm{Mg}$. GFAAS was used for the estimation of $\mathrm{Zn}$ and $\mathrm{Cr}$. 0.1\% Magnesium nitrate was uses as the chemical modifier in the estimation of Zn. Wavelength [Ca (422.7 nm); Mg (285.2 nm); Cr (357.9 nm); Zn (213.9 nm)]. HbA1c was estimated using the ion-exchange HPLC method (BIO-RAD, D10 Haemoglobin A1c programme).

$5 \mathrm{ml}$ of blood samples irrespective of the gender were collected from the out patients of the institute and used for trace metal analysis. The blood was separately collected in tubes containing EDTA which was used for HbA1c assessment. HbA1c determination was based on a 3-min cation exchange chromatography on a special cartridge. The eluted molecules were detected at $415 \mathrm{~nm}$ and estimated from their areas. HbA1c was reported in conventional percentage.

\section{Statistical Analysis}

The statistical analysis of the data was done using (SPSS 19 for Windows). Checked the quantitative variables for normal distribution and summarized variables following normal distribution as mean and standard deviation. Variables not following normal distribution as medians. Spearman's rank correlation was applied to determine the statistical association of the categorical variables. Mann-Whiteney U test to compare median values between two categories of outcome variables. Logistic regression was applied to compute unadjusted odd ratio (95\% confidence Lt). A significance value $(r)>0.7$ and $p<0.05$ has been accepted for all cases.

\section{Observations \& Results}

There were 18 females in group 1 (mean age 45.2 years) and 22 females in group 2 (mean age 45.6 yrs).There was no significant difference with respect to the age and gender distribution of the study participants between the groups. Our study also showed no significant difference in the levels of calcium, magnesium, zinc and chromium among both the groups. But magnesium levels were less than the reference range in both groups (Table 1 and Table 2).

Spearman's rank correlation analysis was performed on the data to find an association between the minerals 
Table 1. Comparison of biochemical parameters between the groups.

\begin{tabular}{ccccc}
\hline Parameters & Reference range. & $\begin{array}{c}\text { Mean } \pm \text { SD in group with } \\
\text { A- }[(\mathbf{H b A 1 c} \leq 7 \%)(\mathbf{n}=\mathbf{3 4})]\end{array}$ & $\begin{array}{c}\text { Mean } \pm \text { SD in group } \\
\text { B-with [(HbA1c } \geq 7 \%)(\mathbf{n}=39)]\end{array}$ & Significance \\
\hline Calcium & $9-1 \mathrm{mg} / \mathrm{dl}$ & $8.89 \pm 2.72 \mathrm{mg} / \mathrm{dl}$ & $9.0 \pm 3.02 \mathrm{mg} / \mathrm{dl}$ & 0.963 \\
Magnesium & $1.7-2.8 \mathrm{mg} / \mathrm{dl}$ & $1.3 \pm 1.0 \mathrm{mg} / \mathrm{dl}$ & $1.2 \pm 0.7 \mathrm{mg} / \mathrm{dl}$ & 0.808 \\
Zinc & $0.1-0.3 \mathrm{mg} / \mathrm{dl}$ & $0.15 \pm 0.02 \mathrm{mg} / \mathrm{dl}$ & $0.13 \pm 0.20 \mathrm{mg} / \mathrm{dl}$ & 0.168 \\
Chromium & $0.1-2 \mu \mathrm{g} / \mathrm{L}$ & $0.15 \pm 0.05 \mu \mathrm{gg} / \mathrm{dl}$ & $0.14 \pm 0.04 \mu \mathrm{g} / \mathrm{dl}$ & 0.603
\end{tabular}

Comparison was by done using Mann-Whiteney U test.

Table 2. Correlations of calcium, magnesium, zinc, chromium and magnesium/zinc with HbA1c.

\begin{tabular}{ccccc}
\hline Parameters & \multicolumn{2}{c}{ Group with A-HbA1c $\leq \mathbf{7 \%}(\mathbf{n}=\mathbf{3 4})$} & \multicolumn{2}{c}{ Group B-with HbA1c $\geq \mathbf{7 \%}(\mathbf{n}=\mathbf{3 9})$} \\
\hline & r value & $\mathbf{p}$ value & r value & p value \\
\hline Calcium & 0.235 & 0.681 & -0.124 & 0.454 \\
Magnesium & 0.157 & 0.374 & -0.78 & $0.042^{*}$ \\
Zinc & 0.48 & 0.785 & -0.82 & $0.049^{*}$ \\
Chromium & -0.166 & 0.347 & -0.86 & $0.021^{*}$ \\
Magnesium/Zinc & 0.244 & 0.164 & 0.74 & $0.04^{*}$ \\
\hline
\end{tabular}

Comparison was by done using Mann-Whiteney U test. ${ }^{*}$ indicate p value $<0.05$, statistically significant.

and glycemic status and there were no significant correlations between $\mathrm{Ca}^{2+}, \mathrm{Mg}^{2+}, \mathrm{Zn}^{2+}$ and $\mathrm{Cr}^{3+}$ with $\mathrm{HbA}_{1 \mathrm{c}}$ levels in group 1. In group 2, significant correlations were seen for $\mathrm{HbA}_{1 \mathrm{c}}$ with $\mathrm{Mg}^{2+}(\mathrm{r}=-0.78, \mathrm{p}=0.042), \mathrm{Zn}^{2+}$ $(r=-0.82, p=0.49), \mathrm{Cr}^{3+}(r=-0.86, p=0.021)$.

We also analyzed the association between ratios of the minerals in both groups by spearman's correlation and found significant association among $\mathrm{Ca}^{2+} / \mathrm{Zn}^{2+}$ and $\mathrm{Ca}^{2+} / \mathrm{Mg}^{2+}$ ratios and $\mathrm{HbA}_{1 \mathrm{c}}$ levels on both groups $(\mathrm{r}=-0.742$ in group $1, r=0.83$ in group 2) with slight increase in significance among group 2. Correlation between $\mathrm{Mg}^{2+} / \mathrm{Cr}^{3+}$ and $\mathrm{Ca}^{2+} / \mathrm{Cr}^{3+}$ was seen in both groups ( $\mathrm{r}=0.959$ in group $1, \mathrm{r}=0.87$ in group 2). Negative correlation between $\mathrm{Cr}^{3+} / \mathrm{Zn}^{2+}$ and $\mathrm{Ca}^{2+} / \mathrm{Cr}^{3+}(\mathrm{r}=0.729, \mathrm{p}=0.013)$ in group 2 was also observed.

\section{Discussion}

Results obtained from this study indicates that there is no significant change in the levels of the parameters between the groups except a slight increase in the Calcium level and slight decrease in the levels of Zinc and Chromium in group 2. This result is in agreement with previous observations [3]-[5]. We have noticed that all the cases irrespective of the groups had $\mathrm{Mg}^{2+}$ levels lower than the reference range and agree with the observations of hypomagnesemia associated with T2DM patients [6].

Niewoener et al. reported that only 9\% of the T2DM patients under study had low serum Zn concentration than the controls and no correlation was observed between serum zinc and $\mathrm{HbA}_{1 \mathrm{c}}$ levels [7]. We have observed negative correlation for the concentration of $\mathrm{Mg}^{2+}, \mathrm{Zn}^{2+}$ and $\mathrm{Cr}^{3+}$ with glycemic status $\left(\mathrm{HbA}_{1 c}\right.$ ) in the group 2 . Our results in this regard agree with the reported inverse correlations of $\mathrm{HbA1c}$ with $\mathrm{Mg}, \mathrm{Zn}$ and $\mathrm{Cr}$ [8]-[10] but against a very recent report in the case of $\mathrm{Zn}$ [11]. We have also found a new significant positive correlation between $\mathrm{Mg} / \mathrm{Zn}$ and $\mathrm{HbA}_{1 \mathrm{c}}$.

Metal ion ratios were suggested more informative than the status of individual mineral concentration, because these ratios are predictive of metabolic dysfunctions and indicative of disease trends [12]. $\mathrm{Ca}^{2+} / \mathrm{Mg}^{2+}$ ratio is very significant in diabetes as they are very decisive in insulin production. Further, elevated inflammatory response associated with magnesium deficiency. Oxidative stress which is at higher degrees in T2DM cases, due to excess flux of glucose in to the polyol pathway, also noted to worsen hypomagnesaemia [13]. Further, serum magnesium levels depend on the status of calcium [14]. A high $\mathrm{Ca}^{2+} / \mathrm{Mg}^{2+}$ ratio as a biomarker for prostate cancer has been suggested. The range of $\mathrm{Ca}^{2+} / \mathrm{Mg}^{2+}$ reported for the entire group of prostate cancer patients was 4.3 
to 4.94 in which a subsection consisting of diabetic patients had values between4.52 and 4.94. In our studies, no significant difference was found in this ratio between the groups 1 and 2 and $\mathrm{Ca}^{2+} / \mathrm{Mg}^{2+}$ was found between 4.4 and 14 with a mean value $0.77 \pm 0.29$. The observed correlation between the ratios $\mathrm{Ca}^{2+} / \mathrm{Mg}^{2}$ and $\mathrm{Ca}^{2+} / \mathrm{Zn}^{2}$ was found in both the groups, but the correlation is found strengthened in group 2 where $\mathrm{HbAlc} \geq 7$.

In an isolated study, $\mathrm{Cu}^{2+} / \mathrm{Zn}^{2}$ ratio was shown significantly higher in cases with T2DM with poor glycemic control [15]. Higher $\mathrm{Cu}^{2+} / \mathrm{Zn}^{2}$ ratio as inflammatory biomarkers for obstructive pulmonary disease [16], autism spectrum disorder [17] and impairment in bone density [18] have been reported. The significant association between the ratios seen in current study throw light in to the relative status of different cations in T2DM. Non redox active metals like $\mathrm{Zn}, \mathrm{Mg}$, Ca etc. which often stabilize the structure of protein compete with the redox active metals like $\mathrm{Cu}, \mathrm{Fe}, \mathrm{Cr}$ etc. for binding sites on proteins, cell membranes and DNA for which coordination number, charge to ionic radius are very important [19].

Substitution of $\mathrm{Zn}^{2+}$ (CN6, ionic radius $\left.0.74 \mathrm{~A}\right)$ for $\mathrm{Cu}^{2+}$ (CN6, ionic radius $\left.0.73 \mathrm{~A}\right)$ in the structure of $\mathrm{Cu}^{2+}$ / $\mathrm{Zn}^{2+}$ superoxide dismutase is reported to maintain 100 reactivity of the enzyme, though results varied with other substitutions [20].

$\mathrm{Zn}^{2+}$ needs special mention in the case of mutual substitutions as it can also exhibit CN4 with radius $0.6 \mathrm{~A}$ and $\mathrm{CN} 5$ with radius $0.68 \mathrm{~A}$. It can be seen that the ionic radii and tendency to form metal-metal bond are very similar for $\mathrm{Zn}^{+2}$ and $\mathrm{Mg}^{+2}$ in crystal structures and $\mathrm{Mg}^{2+}$ caused replacement of $\mathrm{Zn}^{2+}$ from its complexes [21].

We have observed that $\mathrm{Mg}^{2+} / \mathrm{Zn}^{2+}$ not correlated to $\mathrm{HbA}_{1} \mathrm{C}$ in the non-diabetic group but attained significance in the diabetic group. It has been reported that glycemic control in T2DM patients may not correct low $\mathrm{Mg}^{2+}$ concentration suggesting other factors to regulate Mg levels [22]. Further, it was suggested that the association between a low blood $\mathrm{Mg}$ concentration and insulin resistance was related to abnormalities of other cations [23]. Hence we hypothesise that $\mathrm{Mg}^{2+} / \mathrm{Zn}^{2+}$ need attention in the case of type 2 diabetes.

Chromium being a redox active metal differs from $\mathrm{Zn}^{2+}$, $\mathrm{Mg}$ and $\mathrm{Ca}^{2+}$. The role of chromium in the metabolism of sugar is undisputed, but the effect of Cr supplementation in glycemic control is reported conflicting [24]. It is reported recently that $\mathrm{Cr}^{3+}$ influence the activity of the enzyme superoxide dismutase which protects the cells from peroxidation in a dose dependent manner [25]. This observation supports the correlation of $\mathrm{Cr}^{3+} \mathrm{di}^{-}$ rectly and in relation to the other cations with HbA1c.

\section{Conclusion}

T2DM is associated with imbalance in micro and macro nutrient status. The concentrations of Magnesium, Zinc and Chromium were significantly reduced in subjects with $\mathrm{T} 2 \mathrm{DM}$ with $\mathrm{HbA1c} \geq 7$. The ratios of these metal ions were associated significantly with the glycemic status. Monitoring the ratios of these bioactive metal cations is suggested than mere free ion concentration of specific mineral in T2DM patients. Documentation and correction of these micro and macro nutrient imbalances will help in better glycemic control in subjects with T2DM. Regular monitoring of the metal ion ratios will prevent or delay the onset of micro and macro vascular complications of T2DM by alleviating the oxidative stress, systemic inflammation and insulin resistance.

\section{Acknowledgements}

The authors acknowledge their gratitude to Dr. Winny Varghese, Secretary, Mar Athanasius College Association, Kothamangalam, Kerala, for the permission granted to them to avail the facilities at the sophisticated instrumentation centre of the College. One of the authors Dr. Sony Joseph is thankful to Mr. Jain M. George for the friendly technical support.

\section{Conflict of Interest}

The authors declare that we have no conflict of interest in the results of the studies.

\section{References}

[1] Lin, Y. and Sun, Z. (2010) Current Views on Type 2 Diabetes. Journal of Endocrinology, 204, 1-11. http://dx.doi.org/10.1677/JOE-09-0260

[2] Masood, N., Baloch, G.H., Ghori, R.A., Memon, I.A., Memon, M.A. and Memon, M.S. (2009) Serum Zinc and Magnesium in Type-2 Diabetic Patients. Journal of the College of Physicians and Surgeons Pakistan, 19, 483-486. 
[3] Resnick, L.M. (1993) Ionic Basis of Hypertension, Insulin Resistance, Vascular Disease, and Related Disorders. The Mechanism of “Syndrome X”. American Journal of Hypertension, 6, 123S-134S.

[4] Mooradian, A.D. and Morley, J.E. (1987) Micronutrient Status in Diabetes Mellitus. The American Journal of Clinical Nutrition, 45, 877-895.

[5] Flores, C.R., Puga, M.P., Wrobel, K., Garay Sevilla, M.E. and Wrobel, K. (2011) Trace Elements Status in Diabetes Mellitus Type 2: Possible Role of the Interaction between Molybdenum and Copper in the Progress of Typical Complications. Diabetes Research and Clinical Practice, 91, 333-341. http://dx.doi.org/10.1016/j.diabres.2010.12.014

[6] Dasgupta, A., Sarma, D. and Saikia, U.K. (2012) Hypomagnesemia in Type 2 Diabetes Mellitus. Indian Journal of Endocrinology and Metabolism, 16, 1000-1003. http://dx.doi.org/10.4103/2230-8210.103020

[7] Niewoehner, C.B., Allen, J.I., Boosalis, M., Levine, A.S. and Morley, J.E. (1986) Role of Zinc Supplementation in Type II Diabetes Mellitus. The American Journal of Medicine, 81, 63-68. http://dx.doi.org/10.1016/0002-9343(86)90183-X

[8] Khubchandani, A.S. and Sanghan, H. (2013) Study of Serum Magnesium and HbA1c in Diabetic Patients along with Changes in their Lipid Profiles. Indian Journal of Clinical Practice, 23, 717-719.

[9] Saharia, G.K. and Goswami, R.K. (2013) Evaluation of Serum Zinc Status and Glycated Hemoglobin of Type 2 Diabetes Mellitus Patients in a Tertiary Care Hospital of Assam. Journal of Laboratory Physicians, 5, 30-33. http://dx.doi.org/10.4103/0974-2727.115923

[10] Farid, S.M. and Abulfaraj, T.G. (2013) Trace Mineral Status Related to Levels of Glycated Hemoglobin of Type 2 Diabetic Subjects in Jeddah , Saudi Arabia. Medical Journal of Islamic World Academy of Sciences, 21, 47-56. http://dx.doi.org/10.12816/0001489

[11] Dorre, F., Rezvanfar, M. and Ghaseminegad, S. (2014) Comparison of Serum Zinc Level in Patients with Diabetes Type 1 and 2 and Its’ Relation to with HbA1c. Zahedan Journal of Research in Medical Sciences, 16, 48-50.

[12] Kaslow, J.E. (2016) Copper/Zinc Imbalance. http://www.drkaslow.com/html/zinc-copper imbalances.html

[13] Niranjan, G., Mohanavalli, V., Srinivasan, A.R. and Ramesh, R. (2013) Serum Lipid Peroxides and Magnesium Levels Following Three Months of Treatment with Pioglitazone in Patients with Type-2 Diabetes Mellitus. Diabetes \& Metabolic Syndrome: Clinical Research \& Reviews, 7, 35-37. http://dx.doi.org/10.1016/j.dsx.2013.02.020

[14] Huang, J.-H., Tsai, L.-C., Chang, Y.-C. and Cheng, F.-C. (2014) High or Low Calcium Intake Increases Cardiovascular Disease Risks in Older Patients with Type 2 Diabetes. Cardiovascular Diabetology, 13, 120. http://dx.doi.org/10.1186/s12933-014-0120-0

[15] Yerlikaya, F.H., Toker, A. and Arıbaş, A. (2013) Serum Trace Elements in Obese Women with or without Diabetes. Indian Journal of Medical Research, 137, 339-345.

[16] Isik, B., Isik, R.S., Ceylan, A. and Calik, O. (2005) Trace Elements and Oxidative Stress in Chronic Obstructive Pulmonary Disease. Saudi Medical Journal, 26, 1882-1885.

[17] Bjorklund, G. (2013) The Role of Zinc and Copper in Autism Spectrum Disorders. Acta Neurobiologiae Experimentalis, 73, 225-236.

[18] Gaier, E.D., Kleppinger, A., Ralle, M., Mains, R.E., Kenny, A.M. and Eipper, B.A. (2012) High Serum Cu and Cu/Zn Ratios Correlate with Impairments in Bone Density, Physical Performance and Overall Health in a Population of Elderly Men with Frailty Characteristics. Experimental Gerontology, 47, 491-496. http://dx.doi.org/10.1016/j.exger.2012.03.014

[19] Holm, R.H., Kennepohl, P. and Solomon, E.I. (1996) Structural and Functional Aspects of Metal Sites in Biology. Chemical Reviews, 96, 2239-2314. http://dx.doi.org/10.1021/cr9500390

[20] Bertini, I., Luchinat, C. and Monnanni, R. (1985) Zinc Enzymes. Journal of Chemical Education, 62 , 924. http://dx.doi.org/10.1021/ed062p924

[21] Wang, Y., Quillian, B., Wei, P., Wang, H., Yang, X.-J., Xie, Y., King, R. B., Schleyer, P.V.R., Schaefer, H.F. and Robinson, G.H. (2005) On the Chemistry of Zn-Zn Bonds, RZn-ZnR (R = [\{(2,6- $\left.\left.\left.\left.\mathrm{Pr}_{2}^{i} \mathrm{C}_{6} \mathrm{H}_{3}\right) \mathrm{N}(\mathrm{Me}) \mathrm{C}\right\}_{2} \mathrm{CH}\right]\right)$ : Synthesis, Structure, and Computations. Journal of the American Chemical Society, 127, 11944-11945. http://dx.doi.org/10.1021/ja053819r

[22] Eibl, N.L., Kopp, H.P., Nowak, H.R., Schnack, C.J., Hopmeier, P.G. and Schernthaner, G. (1995) Hypomagnesemia in Type II Diabetes: Effect of a 3-Month Replacement Therapy. Diabetes Care, 18, 188-192. http://dx.doi.org/10.2337/diacare.18.2.188

[23] Spencer, H., Norris, C. and Williams, D. (1994) Inhibitory Effects of Zinc on Magnesium Balance and Magnesium Absorption in Man. The Journal of the American College of Nutrition, 13, 479-484. http://dx.doi.org/10.1080/07315724.1994.10718438 
[24] Abdollahi, M., Farshchi, A., Nikfar, S. and Seyedifar, M. (2013) Effect of Chromium on Glucose and Lipid Profiles in Patients with Type 2 Diabetes: A Meta-Analysis Review of Randomized Trials. Journal of Pharmacy \& Pharmaceutical Sciences, 16, 99-114. http://dx.doi.org/10.18433/J3G022

[25] Dlugosz, A., Rembacz, K.P., Pruss, A., Durlak, M. and Lembas-Bogaczyk, J. (2012) Influence of Chromium on the Natural Antioxidant Barrier. Polish Journal of Environmental Studies, 21, 331-335.

\section{Submit or recommend next manuscript to SCIRP and we will provide best service for you:}

Accepting pre-submission inquiries through Email, Facebook, LinkedIn, Twitter, etc. A wide selection of journals (inclusive of 9 subjects, more than 200 journals)

Providing 24-hour high-quality service

User-friendly online submission system

Fair and swift peer-review system

Efficient typesetting and proofreading procedure

Display of the result of downloads and visits, as well as the number of cited articles

Maximum dissemination of your research work

Submit your manuscript at: http://papersubmission.scirp.org/ 